\title{
Geotechnical Investigation of Slopes along the National Highway (NH-1D) from Kargil to Leh, Jammu and Kashmir (India)
}

\author{
Gulzar Hussain, Yudhbir Singh, Ghulam Mohd Bhat \\ Department of Geology, University of Jammu, Jammu, India \\ Email: yudhbirjammu@gamil.com
}

Received 28 January 2015; accepted 26 February 2015; published 2 March 2015

Copyright (C) 2015 by authors and Scientific Research Publishing Inc.

This work is licensed under the Creative Commons Attribution International License (CC BY). http://creativecommons.org/licenses/by/4.0/

(c) (i) Open Access

\begin{abstract}
The national highways are always considered as the economic backbone of the country and have often assisted development work all along their routes. The National Highway (NH-1D) is the most strategic and the only all weather surface link between the two districts of Ladakh region (Kargil and Leh). The area under investigation experiences high vehicular traffic, particularly between March and August, as in the remaining months the Kargil and Leh districts remain cutoff from each other due to bad weather. In recent years, frequent occurrences of slope failures along the highway primarily affect the smooth functioning of the traffic movement which severely affects the life of the people of the area. Strategically, this road network is very important and plays a significant role in transportation and other activities. In order to ensure the stability of road network in the area, it becomes extremely important to understand the triggering mechanism of these failures. The present study made an attempt in this direction and the Slope Mass Rating (SMR) method has been used for slope stability analysis at different locations. The stability of the slopes was also assessed using kinematic analysis conjointly with SMR to identify the types of failure and its potential failure directions associated with each slope. The result obtained after calculating RMR from the selected facets ranges from 11 to 89 with lower values indicating presence of potentially unstable areas. Results have shown that in a total of 20 facets, $65.28 \%$ belong to wedge failure, $22.26 \%$ belong to toppling failure and $12.45 \%$ belong to plane failure.
\end{abstract}

\section{Keywords}

National Highway (NH-1D), Kargil, Leh, RMR, SMR, Kinematic Analysis, Slope Stability

\section{Introduction}

Slope failure has become one of the most frequent geological catastrophes along the road network in the hilly

How to cite this paper: Hussain, G., Singh, Y. and Bhat, G.M. (2015) Geotechnical Investigation of Slopes along the National Highway (NH-1D) from Kargil to Leh, Jammu and Kashmir (India). Geomaterials, 5, 56-67.

http://dx.doi.org/10.4236/gm.2015.52006 
terrain of Himalayan regions that lead to huge loss of life, property and above all the environment. Road construction in hilly areas is often excavated without prior knowledge of geological settings and the quality and conditions of the rock mass. Slope failures are often triggered by a number of external factors such as tectonics, geology, weathering, high relief, erosion processes, and anthropogenic activities. Slope stability analysis is one of the most important interests of geotechnical studies [1]. The stability of slope depends more on the resisting force than the driving force because the driving force is greater than the resisting force which actually causes slope failures. The problem of slope failures has become a chronic problem in many parts of the world. In recent years, a wealth of experience has been accumulated by the geo-scientist in understanding, recognition and treatment of these hazards, but our knowledge is still fragmentary [2]. The growing awareness and concern among the geoscientists to develop the effective procedures to minimize the landslide/slope failure impact in the Himalayan region have helped in the development of the concept and principles of Mountain Risk Engineering (MRE). However, there are areas, in which no work has been done so far, particularly in the Indian context (Kargil to Leh). For example, no serious attempt has been made in this direction to collect the data on structural geometry and sediment characterization to understand the mechanism of these failures. The previous work related to the study area is mostly confined to stratigraphy [3]-[7], palaeontology [8]-[10] and sedimentology [11] [12]. An attempt has been made from the geotechnical view along Jammu-Srinagar national highway (NH1A) in this part of the state [2] [13] [14]. In hilly regions, particularly in Himalaya, road networks are the only lifeline and a way of communication. In recent years, the expansion of road networks in this region has increased many folds which in terms increased the event of landslides/slope failures. The problem of slope stability is being faced throughout history when the fragile balance of natural slopes was disrupted by anthropogenic activities in order to meet the increasing demands of development activities. To meet these pressing demands, the unplanned excavations of slopes for construction and sometimes for widening purposes may disturb the stability of the slopes. In order to ensure the stability of road network it becomes extremely important to understand the triggering mechanism and possible modes of failure.

Understanding of the mechanical properties of intact solid rock is well advanced in rock mechanics, but understanding of the fundamental behavior of discontinuous rock is significantly less developed [15]. The stability analysis determines the condition of natural rock slope and road cut slope in order to investigate potential failure mechanisms to classify them into different hazard zones. The failure mechanisms usually instigate and follow preexisting discontinuities rather than breaking through intact rock. The stability problem of rock slopes along roads in the Himalaya is a major concern in most of the places [16]. It has been revealed that in hilly areas, especially in monsoon season, unplanned excavation of rock slopes for road construction and widening makes the slopes most vulnerable. The Himalayan region is traversed by numbers of structural discontinuities which deformed the rock mass in the area, and a small disturbance (vibrations induced due to blasting) during road construction and widening may prone to failure of slopes in these hilly areas [17] [18].

\section{Study Area}

The study area (Figure 1) lies in Trans-Himalayan region, which had an average height of 3000 to $4000 \mathrm{~m}$ above mean sea level. The topography of the area includes incised valleys and barren mountains cut into very steep and narrow gorges which are devoid of any vegetation cover. The major valleys being longitudinal and are aligned in WNW-ESE direction. The general altitude of the area varies between $2980 \mathrm{~m}$ in the valley and greater than $4500 \mathrm{~m}$ on peaks. In general the study area is characterized by two geomorphic units' i.e. deep gorges of the Indus River and high mountain ranges with glaciers and snow covered peaks of Ladakh ranges. The study area is partly drained by the Indus River and mainly drain by Wakha Chu River which is fed by a number of streams of various orders. Historical records reveal that the region receives rainfall twice in year i.e. June to September and October to May. The region also experiences heavy snowfall which is also the other form of precipitation in the area. There is a great variation in day and night temperature, which contributes towards weathering. The average summer temperature goes up to $20^{\circ} \mathrm{C}$ in July while the average winter temperature dips down to $-15^{\circ} \mathrm{C}$ by January. The high altitude and scanty rainfall in the Ladakh Himalaya explain prolonged cold and arid climate assigning a status of the High Altitude Cold Desert.

\section{General Geological Setup}

The area of investigation (NH-1D) traversing from northwest to southeast through different tectonostratigraphic 


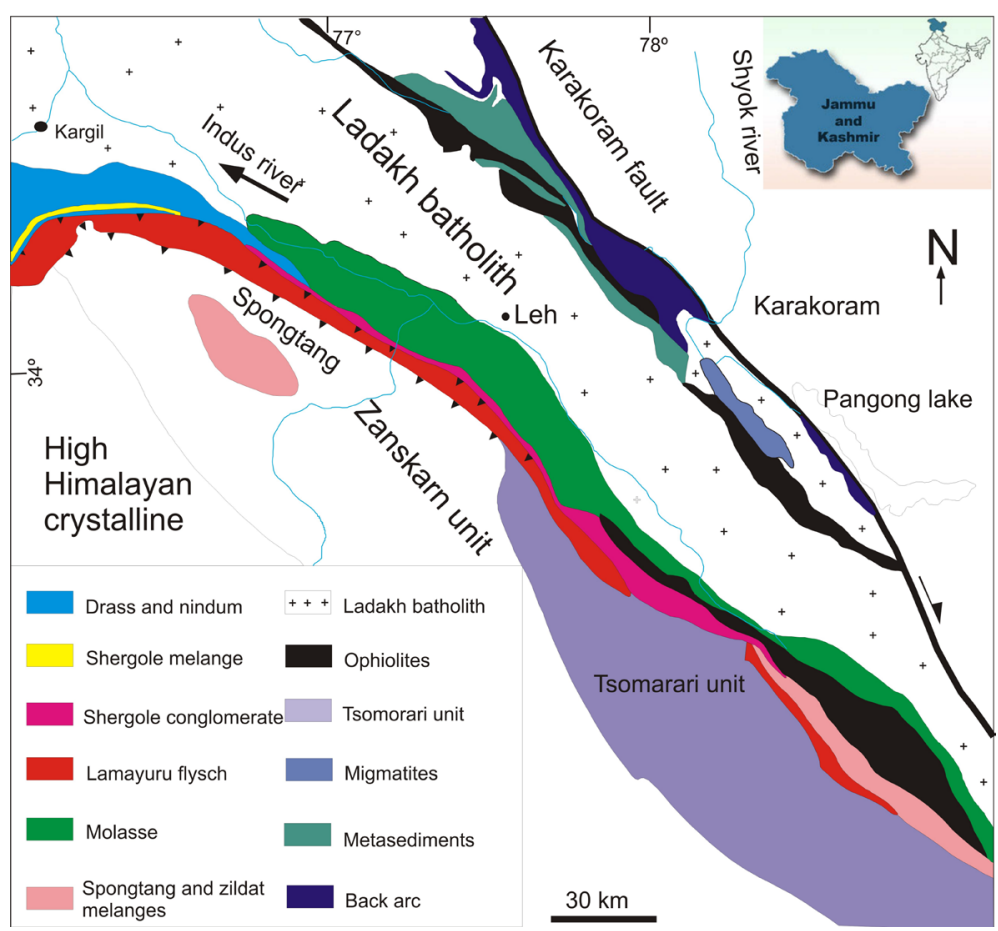

Figure 1. Geological map of Ladakh-Zanskar (modified after Maheo et al., 2000).

units such as Ladakh batholiths at its western extremities comprises a heterogeneous association of granitoid, gabbroid and basic rocks. The Indus Tectonic Zone, which rest unconformably on Ladakh Batholith, has been divided into Indus Group and Sangelungma Group [19]. The Indus Group is further divide into different formation and comprises of a thickly inter-bedded succession of predominantly conglomerate sandstone, siltstone and shale together with sub-ordinate calcareous shale and limestone. The Indus Group also shows a facies variation from east to west. The eastern part represents marine succession and the western part (Indus Mollase of Kargil) represents fresh water facies. The contact between Indus group and Ladakh Batholith is marked by a zone of conglomerate and is comprised of consolidated pebble bed, pebbles, and poorly sorted quartzite, flint porphyritic rocks etc. [20]. Sangelungma Group consist a sequence of sediments and lava flows with Ophiolitic emplacement in the southern part of Indus Tectonic Zone. Sangelungma Group also includes the Drass formation and Ophiolitic Mélange [21] [22]. The contact between Indus Tectonic Zone and Zanskar Formation in east is manifested by Choksti thrust along the northeastern fringe of the Zanskar hill Range. The upliftment of Zanskar hill Range occurred along Choksti thrust during the Miocene, when Himalaya underwent a major upliftment attaining the present height [23] [24].

\section{Methodology}

Hazards related to slopes are triggered by the unique combination of human interference and the controlling factors like lithology, structure, slope angle, relative relief, weathering conditions, climate, landuse and land cover, rock and soil type, precipitation etc. Therefore, keeping in view the above mentioned factors which are responsible for triggering these hazards, a special attention has been paid in this direction to generate the data. Field studies were carried out in order to identify the potential zone of failures and to collect Geotechnical data. In the area under investigation twenty facets were studied and analysed for their potential degree of stability and mode of failure using Slope Mass Rating (SMR) and Rock Mass Rating (RMR) techniques. Slope facets are (the smallest unit of hill slope which has more or less similar characters of slope, showing consistent slope direction and inclination and generally delineated by ridges, spurs, gullies and rivers. Besides these, kinematic analysis is another approach used in the study area on rock slopes to divulge the type and possible direction of failures along the potentially unfavorable joint discontinuities. 


\subsection{Rock Mass Rating (RMR) Technique}

Rock mass rating was introduced by Bieniawski [25] and later on modified [26] [27]. RMR is computed by adding the rating values Table 1 for five parameters [27]. These parameters are, strength of intact rock, RQD, spacing of discontinuities, condition of discontinuities, and ground water condition. On the basis of the RMR value the rock mass is classified into 5 classes, namely: very good (RMR 100 - 81), good (RMR 80 - 61), fair (RMR 60 - 41), poor (RMR 40 - 21), and very poor < 20. The area under investigation has been divided into twenty facets in such a way that each type of rock mass is represented by a separate geological structural unit. The point load test is used to obtain the strength of rock mass and RQD was estimated from number of joints per unit volume [28]. The presence or absence of filling was also noted along with type of filling and hydrological conditions of the slopes were also observed. The results obtained on RMR of this work are given in Table 2.

\subsection{Slope Mass Rating (SMR)}

The SMR (Slope Mass Rating) approach proposed by Romana and is one of the most popular, highly sophisticated and widely used practices to assess the stability of slopes [29]. The slope mass rating approach is based on rock mass rating technique by adding a four factorial adjustment factor $\left(F_{1}, F_{2}, F_{3}, F_{4}\right)$ [25]-[27]. The first three adjustment factors depending on the relative orientation of joints and slope and fourth adjustment factor $\left(F_{4}\right)$ depending on the method of excavation. The SMR values range from 0 to 100 and classified into five different stability classes depend on the obtained values from respective facets Table 3.

$$
\mathrm{SMR}=\mathrm{RMR}+\left(F_{1} \times F_{2} \times F_{3}\right)+F_{4}
$$

\subsection{Kinematic Analyses}

"Kinematic" refers to the motion of bodies without reference to the forces that cause them to move (Goodman, 1989). It is one of the most useful technique used in the recent years to investigate possible failure modes of rock masses which contain joint/discontinuities. The basic modes of failure in the rock masses are plane sliding, wedge sliding and toppling and resulted due to movement of rock blocks on discontinuities. In present study the lower hemispheres stereographical projection method is used [30]-[32]. Planar failure take place if the dip vector (middle point of the great circle) of the great circle representing a discontinuity set and falls within the shaded area (area where the friction angle is higher than slope angle). In case of wedge failure, the failure occurs if the intersection of two great circles representing discontinuities falls within the shaded area (area where the friction

\begin{tabular}{|c|c|c|c|c|c|c|c|c|}
\hline \multirow{2}{*}{$\begin{array}{l}\text { Parameter } \\
\text { Point load } \\
\text { strength }\end{array}$} & \multicolumn{8}{|c|}{ Range of values } \\
\hline & Values & 8 & $4-8$ & $2-4$ & $1-2$ & $\begin{array}{c}\text { Use of } \\
\text { compressive } \\
\text { strength is } \\
\text { preferred }\end{array}$ & Do & do \\
\hline & Rating & 15 & 12 & 7 & 4 & 2 & 1 & 0 \\
\hline \multirow{2}{*}{ RQD } & Values & $90-100$ & $75-90$ & $50-75$ & $25-50$ & $<25$ & & \\
\hline & Rating & 20 & 17 & 13 & 8 & 3 & & \\
\hline \multirow{2}{*}{ Joint spacing } & Values & $>2$ & $0.6-2$ & $0.2-0.6$ & $0.06-0.2$ & $<0.006$ & & \\
\hline & Rating & 20 & 15 & 10 & 8 & 5 & & \\
\hline \multirow[t]{2}{*}{$\begin{array}{c}\text { Joint } \\
\text { condition }\end{array}$} & Values & $\begin{array}{l}\text { Very rough surfaces. } \\
\text { Not continuous } \\
\text { No separation } \\
\text { Unweathered } \\
\text { wall rock }\end{array}$ & $\begin{array}{c}\text { Slightly rough } \\
\text { surfaces } \\
\text { Separation }<1 \mathrm{~mm} \\
\text { Slightly weathered } \\
\text { walls }\end{array}$ & $\begin{array}{c}\text { Slightly rough } \\
\text { surfaces } \\
\text { Separation }<1 \mathrm{~mm} \\
\text { Highly weathered } \\
\text { walls }\end{array}$ & $\begin{array}{c}\text { Slickensided } \\
\text { surfaces. } \\
\text { or Gouge }<5 \mathrm{~mm} \\
\text { thick } \\
\text { or Separation } \\
1-5 \mathrm{~mm} \\
\text { Continuous }\end{array}$ & $\begin{array}{l}\text { Soft gouge }>5 \\
\text { mm thick } \\
\text { or Separation > } \\
5 \mathrm{~mm} \\
\text { Continuous }\end{array}$ & & \\
\hline & Rating & 30 & 25 & 20 & 10 & 0 & & \\
\hline \multirow{2}{*}{$\begin{array}{l}\text { Ground water } \\
\text { condition }\end{array}$} & Values & Completely dry & Damp & Wet & Dripping & flowing & & \\
\hline & Rating & 15 & 10 & 7 & 4 & 0 & & \\
\hline
\end{tabular}


Table 2. Rock mass rating values obtained at different locations in the study area.

\begin{tabular}{|c|c|c|c|c|c|c|c|}
\hline Facet & $\begin{array}{l}\text { Point load strength } \\
\text { rating }\end{array}$ & $\begin{array}{l}\text { RQD from Jv } \\
\text { Rating }\end{array}$ & $\begin{array}{l}\text { Joint spacing } \\
\text { Rating }\end{array}$ & $\begin{array}{l}\text { Joint condition } \\
\text { Rating }\end{array}$ & $\begin{array}{c}\text { Ground water condition } \\
\text { Rating }\end{array}$ & RMR value & Rock class \\
\hline Facet 1 & 12 & 13 & 10 & 19 & 15 & 69 & Good \\
\hline Facet 3 & 12 & 17 & 8 & 20 & 15 & 72 & Good \\
\hline Facet 11 & 12 & 13 & 8 & 21 & 15 & 69 & Good \\
\hline Facet 17 & 12 & 13 & 8 & 22 & 15 & 70 & Good \\
\hline Facet 27 & 12 & 13 & 8 & 22 & 15 & 70 & Good \\
\hline Facet 31 & 15 & 8 & 8 & 20 & 15 & 66 & Good \\
\hline Facet 37 & 7 & 8 & 8 & 17 & 7 & 48 & Fair \\
\hline Facet 43 & 15 & 13 & 8 & 24 & 15 & 75 & Good \\
\hline Facet 45 & 15 & 8 & 8 & 17 & 15 & 63 & Good \\
\hline Facet 52 & 7 & 13 & 8 & 15 & 15 & 48 & Fair \\
\hline Facet 53 & 15 & 13 & 8 & 13 & 15 & 64 & Good \\
\hline Facet 54 & 12 & 13 & 8 & 17 & 10 & 60 & Good \\
\hline Facet 57 & 12 & 13 & 8 & 13 & 15 & 61 & Good \\
\hline Facet 58 & 15 & 8 & 8 & 13 & 15 & 59 & Good \\
\hline Facet 60 & 12 & 8 & 8 & 20 & 15 & 63 & Good \\
\hline Facet 63 & 12 & 8 & 10 & 20 & 15 & 65 & Good \\
\hline Facet 67 & 12 & 8 & 15 & 13 & 15 & 63 & Good \\
\hline Facet 68 & 12 & 8 & 8 & 20 & 15 & 63 & Good \\
\hline Facet 70 & 7 & 8 & 8 & 15 & 15 & 53 & Fair \\
\hline Facet 71 & 7 & 8 & 8 & 18 & 18 & 15 & Very poor \\
\hline
\end{tabular}

Table 3. Description of SMR classes (Romana, 1985).

\begin{tabular}{|c|c|c|c|c|c|}
\hline Class No. & $\mathrm{v}$ & iv & iii & ii & $\mathrm{i}$ \\
\hline SMR value & $0-20$ & $21-40$ & $41-60$ & $61-80$ & $81-100$ \\
\hline $\begin{array}{l}\text { Rock mass } \\
\text { description }\end{array}$ & Very bad & Bad & Normal & Good & Very good \\
\hline Stability & Completely unstable & Unstable & Partially stable & Stable & Completely stable \\
\hline Failures & $\begin{array}{l}\text { Big planar or soil like } \\
\text { circular }\end{array}$ & $\begin{array}{l}\text { Planar or big } \\
\text { wedges }\end{array}$ & $\begin{array}{c}\text { Planar along some joint and many } \\
\text { wedges }\end{array}$ & $\begin{array}{l}\text { Some block } \\
\text { failure }\end{array}$ & No failure \\
\hline $\begin{array}{l}\text { Probability of } \\
\text { failure }\end{array}$ & 0.9 & 0.6 & 0.4 & 0.2 & 0 \\
\hline
\end{tabular}

angle is higher than slope angle). Finally the toppling failure, it is based on a two dimensional relationship and occurs when the centre point of the great circle (i.e. dip vector) falls in the triangular shaded zone of equal area stereographic projection.

In area under investigation twenty facets were studied for kinematic analysis and from these facets the joint/ discontinuities and slope data were obtained on various aspects. Then data obtained from these aspects were applied for stereographic projection then these facets are classified Table 4 accordingly from the obtained values. Out of twenty facets, one facet is completely stable, eight facets fall in stable class and seven facets fall in partially stable class. In remaining four facets two facets are unstable and two facets are completely unstable. Figure 2 shows different classes of stability the study area. The stereographic projections of facets which fall in unstable and completely unstable class of SMR are shown in Figure 3. 
Table 4. Showing RMR and SMR results obtained from the study area.

\begin{tabular}{|c|c|c|c|c|c|c|}
\hline S. No & Facet no. & RMR & SMR & Observed failure & Stability & Failure index \\
\hline 1 & Facet 1 & 69 & $\mathrm{~W} 1=67.35, \mathrm{~W} 2=43$ & Wedge & Partially stable & $\mathrm{W}=0.67$ \\
\hline 2 & Facet 3 & 72 & $\mathrm{~J} 3=80$ & Some block failure & Stable & \\
\hline 3 & Facet 11 & 69 & $\begin{array}{l}\mathrm{W} 1=84 \\
\mathrm{~W} 2=89 \\
\mathrm{~T} 1=84\end{array}$ & Wedge and toppling & Completely stable & $\begin{array}{l}\mathrm{W}=0.2 \\
\mathrm{~T}=0.2\end{array}$ \\
\hline 4 & Facet 17 & 70 & $\mathrm{~T}=47$ & Toppling & Partially stable & $\mathrm{T}=0.33$ \\
\hline 5 & Facet 27 & 70 & $\begin{array}{l}\mathrm{W} 1=76 \\
\mathrm{P}=76\end{array}$ & Wedge and planar & Stable & $\begin{array}{l}W=0.33 \\
P=0.33\end{array}$ \\
\hline 6 & Facet 31 & 66 & $\mathrm{~W} 1=75$ & Wedge & Stable & $\mathrm{W}=0.33$ \\
\hline 7 & Facet 37 & 48 & $\begin{array}{l}\mathrm{W} 1=34 \\
\mathrm{~T}=58\end{array}$ & Wedge and toppling & Unstable & $\begin{array}{l}\mathrm{W}=0.17 \\
\mathrm{~T}=0.25\end{array}$ \\
\hline 8 & Facet 43 & 75 & $\mathrm{~W} 1=35$ & Wedge & Partially stable & $\mathrm{W}=0.33$ \\
\hline 9 & Facet 45 & 63 & $\mathrm{~W} 1=72$ & Wedge & Stable & $\mathrm{W}=0.33$ \\
\hline 10 & Facet52 & 48 & $\mathrm{~W} 1=21$ & Wedge & Completely unstable & $\mathrm{W}=0.33$ \\
\hline 11 & Facet 53 & 64 & $\mathrm{~W} 1=59$ & Wedge & Partially stable & $\mathrm{W}=0.33$ \\
\hline 12 & Facet 54 & 60 & $\mathrm{~T}=58$ & Toppling & Partially stable & $\mathrm{T}=0.33$ \\
\hline 13 & Facet 57 & 61 & $\begin{array}{l}\mathrm{P}=52 \\
\mathrm{~T}=72\end{array}$ & Planar & Partially stable & $\begin{array}{l}\mathrm{T}=0.33 \\
\mathrm{P}=0.33\end{array}$ \\
\hline 14 & Facet 58 & 59 & $\mathrm{~W} 1=54$ & Wedge & Partially stable & $\mathrm{W}=0.17$ \\
\hline 15 & Facet 60 & 63 & $\mathrm{~W}=72$ & Wedge & Stable & $\mathrm{W}=0.17$ \\
\hline 16 & Facet 63 & 65 & $\mathrm{~W} 1=72$ & Wedge & Stable & $\mathrm{W}=0.17$ \\
\hline 17 & Facet 67 & 63 & $\mathrm{~W} 1=69$ & Wedge & Stable & $\mathrm{W}=0.33$ \\
\hline 18 & Facet 68 & 63 & $\mathrm{~W} 1=61$ & Wedge & Stable & $\mathrm{W}=0.33$ \\
\hline 19 & Facet 70 & 53 & $\begin{array}{c}\mathrm{W} 1=59 \\
\mathrm{P}=26 \\
\mathrm{~T}=68\end{array}$ & $\begin{array}{c}\text { Wedge } \\
\text { Planar and toppling }\end{array}$ & Unstable & $\begin{array}{l}\mathrm{W}=0.33 \\
\mathrm{P}=0.33 \\
\mathrm{~T}=0.33\end{array}$ \\
\hline 20 & Facet 71 & 56 & $\begin{array}{l}\mathrm{W} 1=11 \\
\mathrm{~W} 2=28\end{array}$ & Wedge & Completely unstable & $\mathrm{W}=0.67$ \\
\hline
\end{tabular}

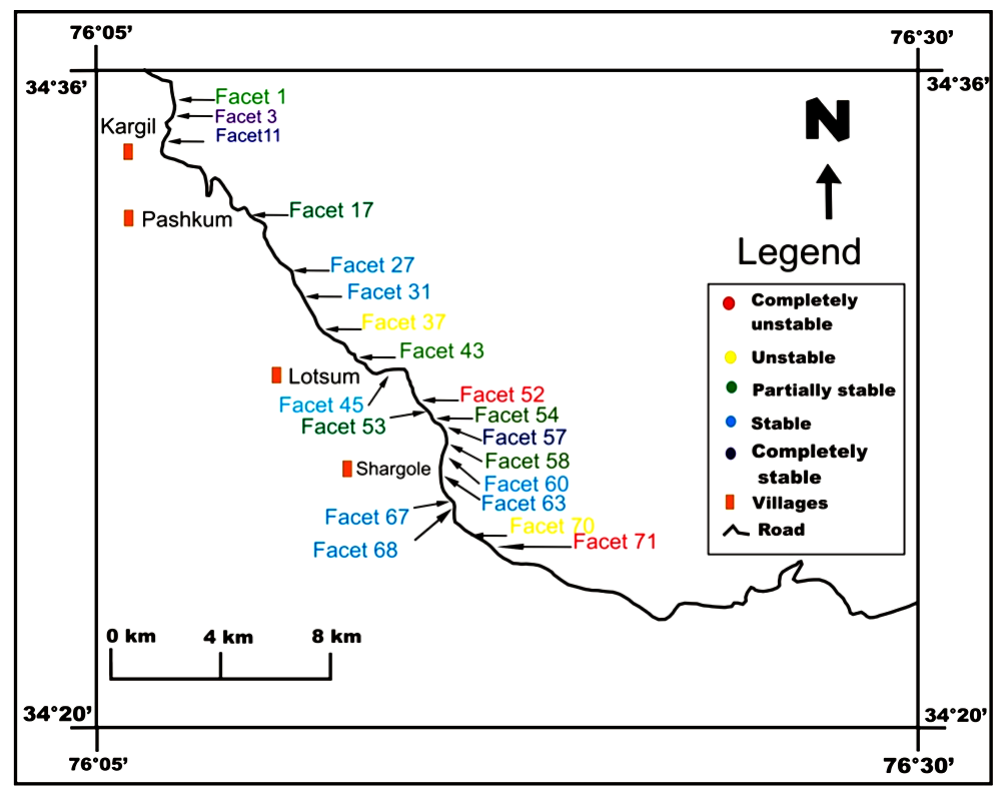

Figure 2. Map showing important locations, facets with failure classes in the study area. 


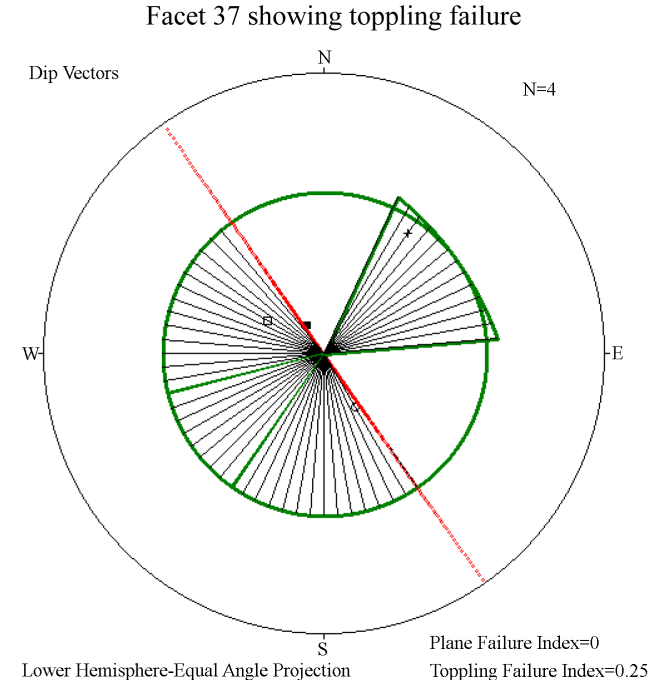

Facet 52 showing wedge failure

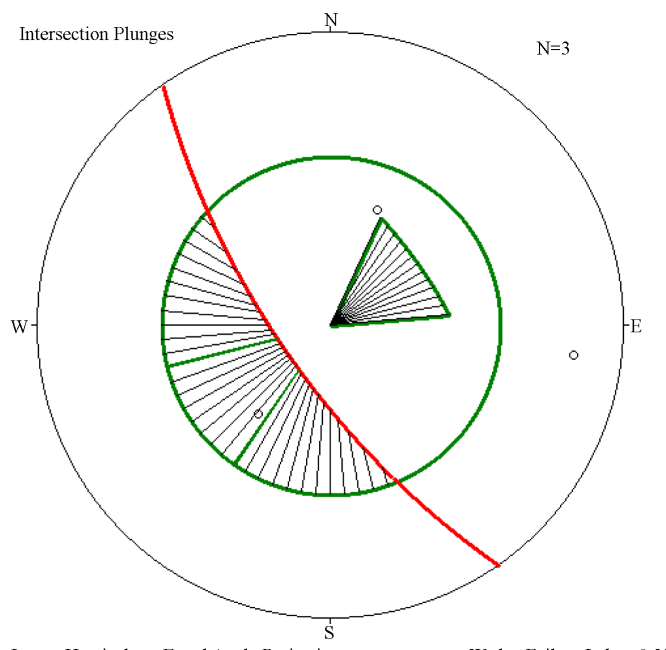

Lower Hemisphere-Equal Angle Projection

Wedge Failure Index $=0.33$

Facet 70 showing plane and wedge failure.

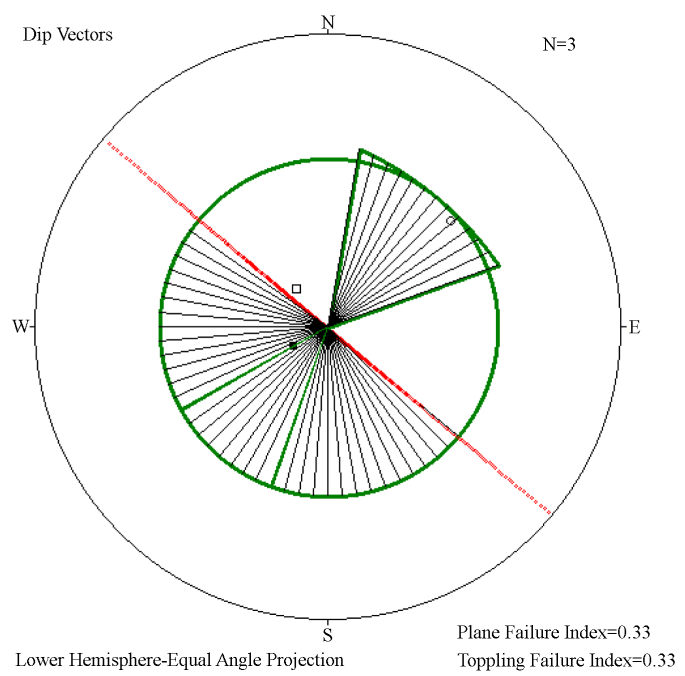

Facet 37 showing wedge failure

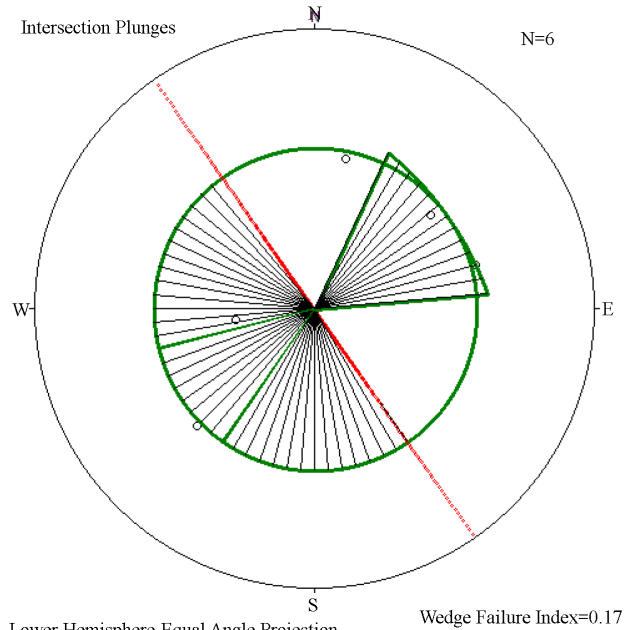

Facet 70 showing wedge failure

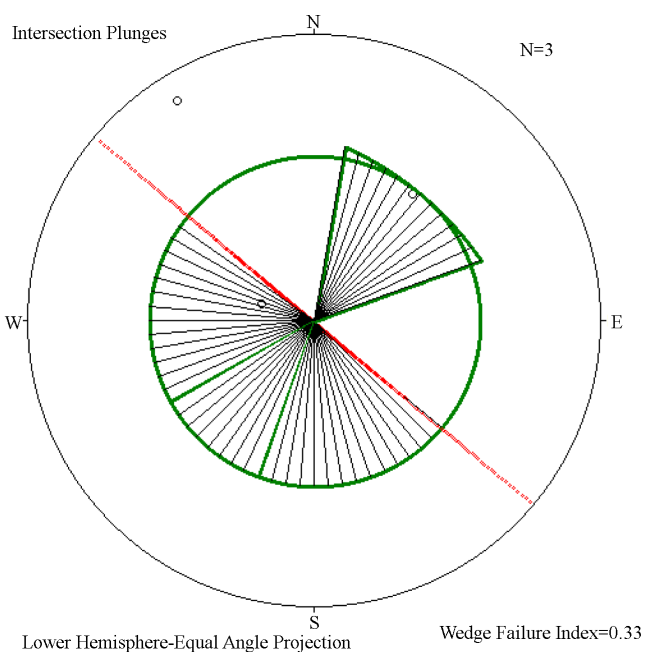

Facet no. 71 showing wedge failure

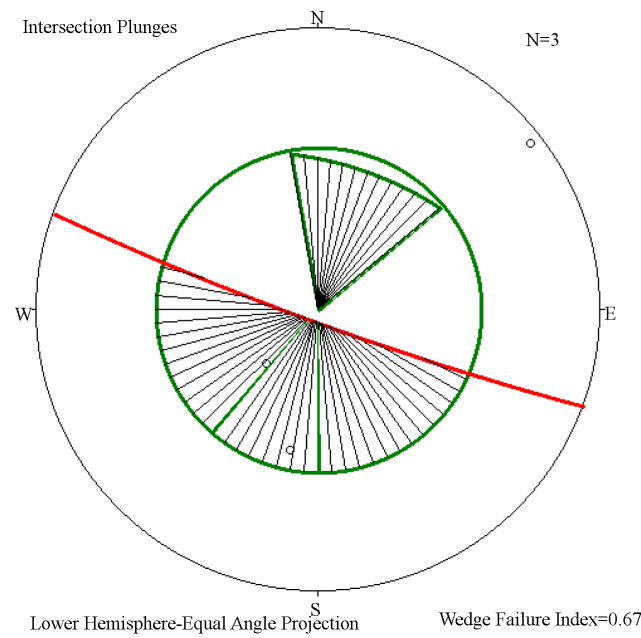

Figure 3. Showing stereographic projection of unstable and completely unstable class in the study area. 


\section{Result and Conclusion}

The basic objective of the present study is to investigate some cut slopes along national highway 1D in order to analyze them using Rock Mass Rating, Slope Mass Rating (SMR) and kinematic approach. The NH-1D is a very important road network in this part of Himalaya strategically and commercially. The area also remains virgin in such study. The main aim of present study is to identify the potential failure locations and to understand the failure mechanism. The joint density in the study area ranges from 02.50 to $14.00 \mathrm{~m} / \mathrm{m}^{3}$. The highest value of joint density is recorded in facet $70\left(14.00 \mathrm{~m} / \mathrm{m}^{3}\right)$ and the lowest joint density is recorded in facet 3 . The RMR value obtained from the study area ranges from 11 to 89, representing all five classes i.e. very good, good, fair, poor and very poor. The highest RMR value is obtained in facets 43 and the lowest in facet 71 .

In the given study, the SMR technique has also been used to classify the rock slopes into different classes. The biggest advantage of SMR technique is that it provides slope description, stability and observed failures. In the given study, the SMR data reveal that twenty facets studied were fallen in all the five stability classes i.e. completely unstable, unstable, stable, partially stable and stable. The results obtained for each facet of SMR and RMR were compared with each respective facet and it clearly reveals that the stability of rock slope is independent on the rock mass rating and is completely dependent on the orientation of discontinuities/joints, slope angle and friction angle (Figure 4). The kinematic analysis also reveals that mostly joint planes intersect with each other and form different potential failures. The study also infers that out of twenty factes, $65.28 \%$ factes in the study area belong to wedge failure, $22.26 \%$ factes belong to toppling failure and $12.45 \%$ factes belong to plane failure (Figure 5).

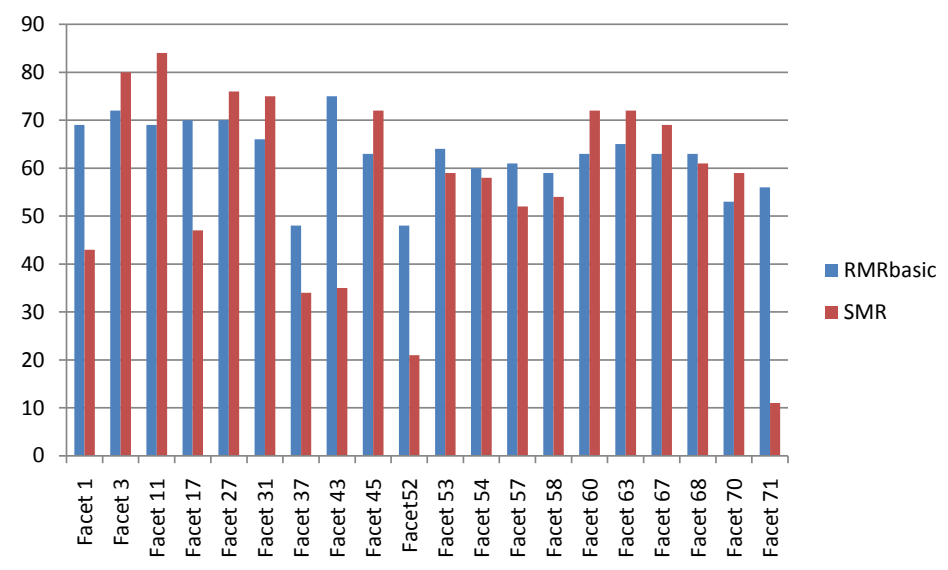

Figure 4. The diagram showing comparison of observed RMR and SMR values of different facets in the study area.

\section{percentage of failures}

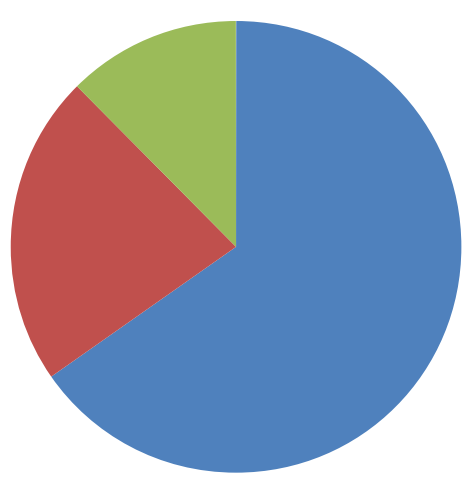

$$
\begin{aligned}
& \text { wedge failure } \\
& \text { toppling failure } \\
& \text { plane failure }
\end{aligned}
$$

Figure 5. The given chart showing percentage of different failure in the study area. 


\section{Acknowledgements}

Gulzar Hussain express thanks to the joint CSIR-UGC for the fellowship grant and support.

\section{References}

[1] Kramer, S.L. (1996) Geotechnical Earthquake Engineering. Prentice-Hall Civil Engineering and Engineering Mechanics Series, Prentice Hall, Upper Saddle River, 653.

[2] Singh, Y. (2006) Geotechnical and Structural Evaluation of Tectonostratigraphic Units along the National Highway, NH-1A between Udhampur and Batote Jammu Himalaya. Ph.D. Thesis, University of Jammu, Jammu, Unpublished.

[3] Wadia, D.N. (1928) The Geology of the Poonch State, Kashmir and Adjacent Parts of the Panjab. Memoirs of the Geological Survey of India, 51, 233.

[4] Wadia, D.N. (1937) The Cretaceous Volcanic Series of Astor-Deosai Kashmir and Is Intrusion. Record Geological Survey of India, 72, 151-161.

[5] Sharma, V.P., Verma, S.N. and Sharma, A.R. (1979) Structure and Stratigraphy of Ramban-Banihal-Galabgarh- Budhil Sector of Pir Panjal Range, Jammu and Kashmir State. Geological Survey of India, 41, 337-351.

[6] Srikantia, S.V. (1973) The Tectonic and Stratigraphic Position “Panjal Volcanics” in Kashmir Himalaya-A Reappraisal. Himalayan Geology, 3, 59-71.

[7] Srikantia, S.V. and Bhargava, O.N. (1974) The Salkhala and Jutogh Relationship in the Kashmir and Himachal Himalaya-A Reappraisal. Himalayan Geology, 4, 396-413.

[8] Kundal, S.N. (2013) Late Pliocene (Piacenzian Stage) Fossil Molluscs from Upper Siwalik Subgroup of Jammu, Jammu and Kashmir, India. International Research Journal of Earth Sciences, 1, 31-38.

[9] Parmar, V. (2013) Fossil Molluscs from the Middle Miocene Lower Siwalik Deposits of Jammu, India. International Research Journal of Earth Sciences, 1, 16-23.

[10] Parmar, V. and Jigmet, T. (2014) First Fossil Discoglossinae (Anura) from the Siwaliks of the Indian Subcontinent. International Research Journal of Earth Sciences, 2, 1-6.

[11] Bhatia, T.R. and Bhatia, S.K. (1973) Sedimentology of the Slate Belt of Ramban-Banihal Area, Kashmir Himalaya. Himalayan Geology, 3, 116-134.

[12] Bhat, G.M. and Pandita, S.K. (1997) Turbidite to Storm Transition Sedimentation during Early Carboniferous, Kashmir Himalaya. Journal of the Geological Society of India, 49, 545-558.

[13] Bhat, G.M., Pandita, S.K., Dhar, B.L., Sahni, A.K. and Haq, IHSAN-UL (2002) Preliminary Geotechnical Investigation of Slope Failures along Jammu-Srinagar National Highway between Batote and Banihal. Reprinted from Aspects of Geology Environment of the Himalaya, 275-288.

[14] Andrabi, S.I.H. (2002) Evaluation of Sediment Attributes and Structural Geometry of Tectonostratigraphic Units along the National Highway between Batote and Banihal, Jammu \& Kashmir (India). Unpublished Ph.D. Thesis, University of Jammu, Jammu.

[15] Norberth, M. (2000) Highway Rock Cut Stability Assessment in Rock Masses Not Conducive to Stability Calculations. Proceedings of the 51st Annual Highway Geology Symposium, Seattle, 29 August-1 September 2000, 249-259.

[16] Umrao, R.K., Singh, R., Ahmad, M. and Singh, T.N. (2011) Stability Analysis of Cut Slopes Using Continuous Slope Mass Rating and Kinematic Analysis in Rudraprayag District, Uttarakhand. Geomaterials, 1, 79-87. http://dx.doi.org/10.4236/gm.2011.13012

[17] Rautela, P. and Pande, R.K. (2005) Traditional Inputs in Disaster Management: The Case of Amparav, North India, International Journal of Environmental Studies, 62, 505-515.

[18] Uniyal, A. and Pande, R.K. (2003) The Fury of Nature in Uttaranchal: Uttarkashi Landslide of the Year. Disaster Prevention and Management, 16, 562-575.

[19] Srikantia, S.V. and Razdan, M.L. (1980) Geology of Part of Central Ladakh Himalaya with Particular Reference to the Indus Tectonic Zone. Journal of the Geological Society of India, 21, 523-545.

[20] Tewari, A.P. (1964) On the Upper Tertiary Deposits of Ladakh Himalayas and Correlation of Various Geotectonic Units of Ladakh with Those of Kumaon, Tibet Region. Proceedings of the 22nd International Geological Congress, 11, 37-58.

[21] Shah, S.K., Sharma, M.L., Gergan, J.T. and Tara, C.S. (1976) Stratigraphy and Structure of Western Part of Indus Suture Belt, Ladakh North-Western Himalaya. Himalayan Geology, 6, 534-556.

[22] Gansser, A. (1977) The Great Suture Zone between Himalaya and Tibet: A Preliminary Account. Himalaya-sciences de la terra Colloqes International, 7-10 December 1976, Editions du Centre National de la Researche Scientifique, 
Paris, 268, 181-192.

[23] Thakur, V.C. (1981) Regional Framework and Geodynamic Evolution of Indus Tsangpo Suture Zone in Ladakh Himalayas. Transactions of the Royal Society of Edinburgh: Earth Sciences, 72, 89-97. http://dx.doi.org/10.1017/S0263593300009925

[24] Sinclair, H.D. and Jaffey, N. (2001) Sedimentology of the Indus Group, Ladakh, Northern India Implications for the Timing of Initiation of the Palaeo-Indus River. Journal of the Geological Society, London, 158, 151-162. http://dx.doi.org/10.1144/jgs.158.1.151

[25] Bieniawski, Z.T. (1973) Engineering Classification of Jointed Rock Masses. Transactions of the South African Institution of Civil Engineers, 15, 355-344.

[26] Bieniawski, Z.T. (1979) The Geomechanical Classification in Rock Engineering Applications. Proceedings of the 4th International Congress Rock Mechanics, Montreux, 2-8 September 1979, 41-48.

[27] Bieniawski, Z.T. (1989) Engineering Rock Mass Classifications. Wiley-Interscience, New York.

[28] Palmstrom, A. (2005) Measurements of and Correlations between Block Size and Rock Quality Designation (RQD). Tunnelling and Underground Space Technology, 20, 362-377. http://dx.doi.org/10.1016/j.tust.2005.01.005

[29] Romana, M. (1985) New Adjustment Ratings for Application of Bieniawski Classification to Slopes. Proceedings of International Symposium on the Role of Rock Mechanics, International Society for Rock Mechanics, Salzburg, 49-53

[30] Hoek, E. and Bray, J. (1981) Rock Slope Engineering. Revised 2nd Edition, The Institution of Mining and Metallurgy, London.

[31] Goodman, R.E. (1989) Introduction to Rock Mechanics. Wiley, New York.

[32] Watts, C.F. (2003) User’s Manual Rockpack III for Windows, Rock Slope Stability Computerized Analysis Package, Part One-Stereonet Analyses. C.F. Watts \& Associates. 


\section{Appendix}

Field photographs in study area

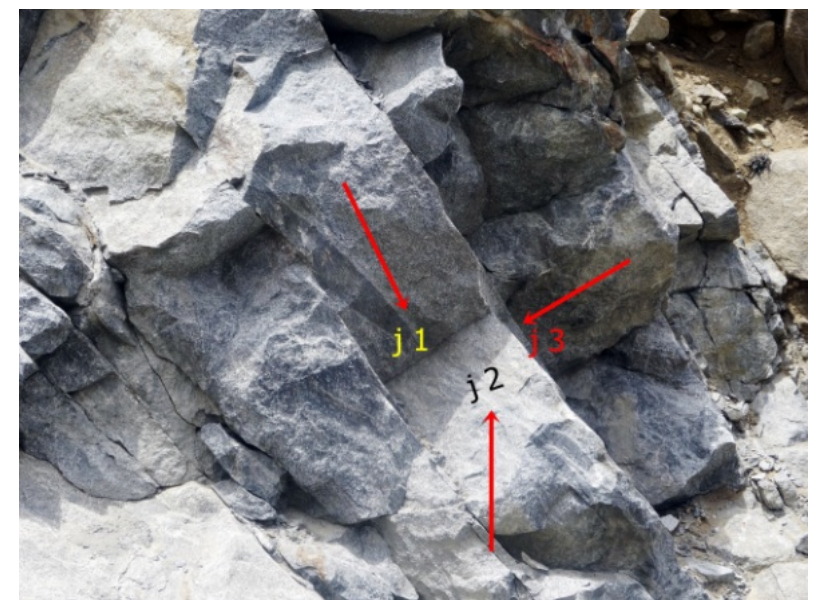

Three set joint in facet 1 .

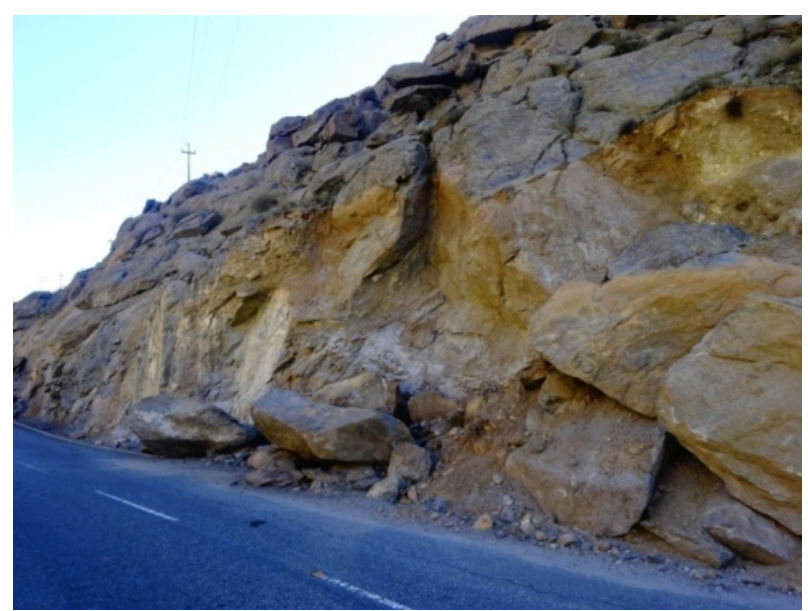

Facet no. 1 showing wedge failure.

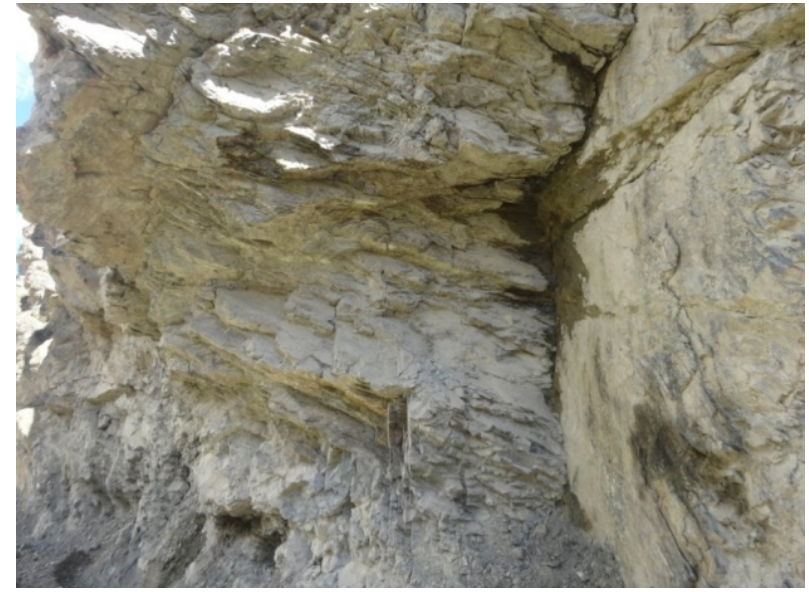

Highly fractured facet no. 58 showing damp area prone to failure. 


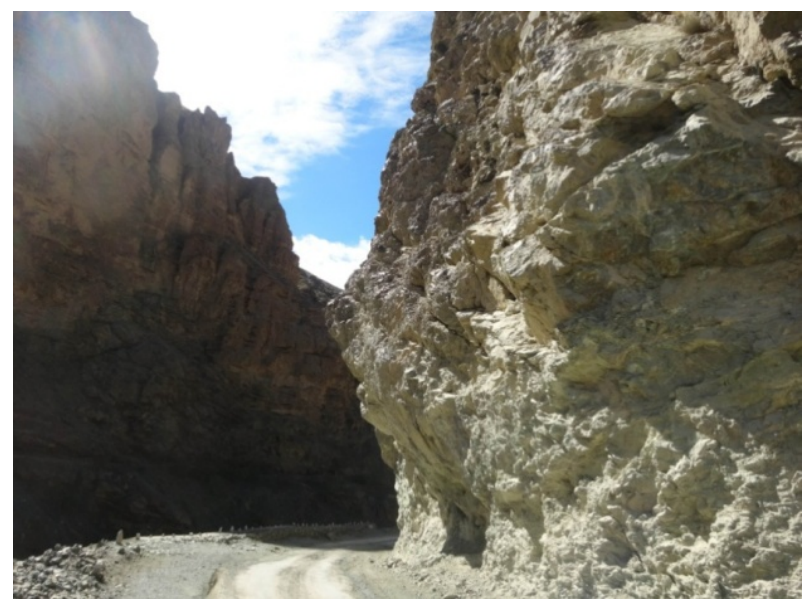

Facet 37 highly block and undercutting prone to toppling failure. 